\title{
A quantitative content analysis of Turkish state universities' official websites in terms of their preparedness and actions during emergency distance education in the early phase of the COVID-19 pandemic period
}

\author{
Sinan Keskin ${ }^{1}$ D $\cdot$ Murat Çinar $^{2}$ D $\cdot$ Ömer Demir $^{3}$ (D)
}

Received: 5 December 2020 / Accepted: 8 September 2021 / Published online: 15 October 2021

(C) The Author(s), under exclusive licence to Springer Science+Business Media, LLC, part of Springer Nature 2021

\begin{abstract}
Most universities worldwide had to temporarily interrupt face-to-face education and start Emergency Distance Education (EDE) due to the COVID-19 outbreak. It is useful to identify the difficulties and problems that universities faced in this process in order that they can carry out a similar process more efficiently in the future. Therefore, this study aimed to conduct an in vivo examination of EDE from the institutional perspective within the scope of universities during the pandemic period in Turkey. To this end, all state university websites were searched according to 27 criteria which were determined to set out the EDE readiness status of universities. The results revealed that higher education institutions had difficulty in providing sufficient pedagogical and technical guidance to academic staff due to the rapid transition. With respect to students, distance course contents, activities and announcements were not equitably accessible for students from foreign countries and those with disabilities owing to the lack of information and communications technology (ICT) tools, internet connection, translation, etc. A remarkable number of higher education institutions preferred the features of distance education tools such as cost, familiarity, stability, availability of technical support, and short preparation time rather than their pedagogical affordances.
\end{abstract}

Keywords Distance education centers - Emergency distance education - COVID19 · Higher education institutions · Rapid instructional design · Quantitative content analysis

Sinan Keskin

sinankeskin@yyu.edu.tr

1 Van Yuzuncu Yil University, Faculty of Education, 65000 Tusba, Van, Turkey

2 Republic of Turkey Ministry of National Education, Borsa İstanbul Vocational and Technical Anatolian High School, Adana, Turkey

3 Hakkari University, Faculty of Education, Hakkari, Turkey 


\section{Introduction}

Continuing education in local and global emergencies (war, internal conflict, natural disaster, pandemic, etc.) is one of the leading concerns of the international community. The issue of how education activities can continue in emergencies has been discussed in the literature since the 1990s under the title of "emergency education" (Kagawa, 2005; Sinclair, 2002). Especially in the period corresponding to these years, there are studies related to rapid education initiatives in emergencies after the occurrence of wars and internal conflicts (e.g., Bosnia, Rwanda, Kosovo, Sudan, Sierra Leone, Gulf region countries) (Aguilar \& Retamal, 1998; Betancourt et al., 2008; Retamal et al., 1998). Similarly, in 2003, due to the SARS-CoV disease, several studies that addressed the process of transition to Emergency Distance Education (EDE) (Fox, 2007; Fung \& Ledesma, 2005) were conducted in many Asia-Pacific countries. However, research on education in emergency situations (or crisis) is still scarce, and this phenomenon is mostly addressed in the reports and other publications of non-governmental organizations and media agencies. Today, with the announcement of COVID-19 as a pandemic, the concept of EDE has come onto the agenda again. In this process, maintaining physical distance between people is of great importance in preventing the spread of the disease. For this reason, the search for a strategy and method for continuing educational activities without bringing people together in physical spaces has emerged. In this study, the precautions taken and strategies followed by Turkish state universities in the context of EDE in the pandemic process were examined.

\subsection{Emergency distance education}

Emergency education is conceptualized as an education type that promotes learning opportunities that provide students with social, emotional, cognitive, and physical development in crises (Sinclair, 2002). It is also described as the education given when students cannot access national education systems due to extraordinary conditions (Nicolai \& Triplehorn, 2003). When it comes to emergencies, even though human crises such as internal conflict, war, terror incidents, and natural disasters like flood, earthquake, and tsunamis may come to mind, there are also silent emergencies such as pandemics, poverty, and social inequalities. Although the impact of emergencies is mostly regional, occasionally global emergencies may occur. Epidemics (AIDS, Plague, Sars, Influenza, etc.) are prominent examples of these. Despite not being pertinent for every type of emergency, distance education (DE) has an important potential role for the provision of emergency education services, provided that technological infrastructure can be brought to everyone. In fact, it may be the only alternative in epidemic situations where physical distance between people should be maintained. For example, owing to the SARS-CoV disease in 2003, face-to-face education was interrupted in many Asia-Pacific countries, primarily in Hong Kong and Singapore. In this period, web-based EDE activities were carried out to ensure that students continued learning in a way that was free from the risk of infectious 
disease (Fung \& Ledesma, 2005). As a result, the SARS outbreak made it clear that students need to access their schools remotely in emergencies such as pandemics.

In the DE literature, EDE has also been conceptualized as Emergency Remote Teaching, which has gained popularity nowadays. In the first half of 2020, face-toface education was interrupted all over the world because of the new type of SARSCoV epidemic (COVID-19). This was declared to be a pandemic by the World Health Organization (WHO) on 12 March 2020. Consequently, maintaining physical distance between people is of great importance in preventing the spread of the disease. For this reason, the search for a strategy and method for continuing educational activities without bringing people together in physical spaces has emerged. In this period, education activities for students who were confined to homes all over the world were urgently sought to be met through DE. During this period, the decision was made to conduct all educational activities through DE, either synchronously or asynchronously. The transition to DE has been a temporary solution rather than a permanent one until normality could resume. As a matter of fact, this is the most important issue that distinguishes emergency remote teaching from DE. In the former, the transition to DE is both temporary and fast. Besides, flexible options such as modality, pacing, feedback, and assessment of DE are not always possible in emergency remote teaching (Hodges et al., 2020). The transition to EDE that took place during the COVID-19 pandemic process can be considered as an emergency remote teaching application. In this context, this study aimed to take a snapshot to describe how the EDE process was administered by state higher education institutions in Turkey during the COVID-19 pandemic.

\subsection{The importance of instructional design in DE}

Instructional design is one of the concepts handled in every period despite the differences observed in technological developments, theoretical orientations, and research tendencies in the field of DE, just as in face-to-face education (Zawacki-Richter \& Naidu, 2016). In fact, when the literature over the past 40 years is analyzed, it can be seen that studies on instructional design issues such as curriculum design, course content, and preparation of learning materials, following the structuring, organization, and management of DE institutions, have accelerated. It is apparent that in the period following the first term of academic endeavors, studies are undertaken to increase the quality of DE applications in terms of the teaching and learning experience, and to develop opportunities for interaction, communication, and collaboration (Zawacki-Richter \& Naidu, 2016). The most important concern of the researchers in this process was that DE should be implemented in a way that does not fall behind face-to-face education. Recently, massive open online courses (MOOCs), open online course resources, and open universities have stood out among the primary research trends in DE (Zawacki-Richter et al., 2018). Instructional design is not a concept unique to face-to-face teaching. Although the instructional design for DE contains components that are common with face-to-face education, it also contains several different components that result from using communication technologies (Tüzün \& Çınar, 2016). 
Moore and Kearsley (1996) pointed out the importance of the systemic approach by stating that $\mathrm{DE}$ should not be misunderstood as merely integrating technology into courses or moving courses to the web. Irrespective of their scale, DE components must be designed in an interrelated way, creating harmony with each other. This requires detailed planning and analysis beyond the decision of what to teach with these DE technologies and which technologies are to be used in DE. Course design in DE is a process that requires expertise in different fields. Therefore, DE course design would be best run by a team comprising a subject area expert, instructional technologist, graphic designer, data analyst, producer, etc. The design and implementation of DE courses require both instructional design and technical skills. However, from time to time there may be situations where there is not enough support in terms of human resources with these skills as well as technological infrastructure. Most of the problems experienced in the DE process arose from the inability of the institutions to reach these supports (Erdem-Aydin, 2021; Trust \& Whalen, 2020).

Instructional design principles guide all instructional practices regardless of the mode of teaching and learning delivery. However, how the principles are applied, what the instructional design components are, how they are shaped (the roles of the students and teachers/academic staff, teaching methods, learning tasks, the design of the materials, the choice of learning contexts, etc.) can differ significantly according to the modality of education. In traditional instructional processes, the needs are predetermined, and a suitable pedagogical framework is created. On the other hand, in DE, the pairing between pedagogical structures and technological/technical infrastructure elements and competencies can lead to tensions and differences in determining pedagogical route maps (Tüzün \& Çınar, 2016). The use of instructional strategies in DE is strictly dependent on appropriate software tools. Cost is an important determinant in the selection of the software tools. Also, tool features and marketing conditions can change rapidly over time. In summary, unlike face-to-face education, technological and pedagogical design elements mutually affect each other in DE settings. Rigorous analysis is required, especially for the design of instruction and its implementation on the web. On the other hand, the instructional nature of distance courses is often criticized (Margaryan et al., 2015). Despite the guidance of general qualified instructional design principles, how to use these principles in $\mathrm{DE}$ environments is an important problem. DE course design has a different instructional design ecosystem. Therefore, there is a need for instructional design theories and models to guide DE (Boulton, 2002; Shearer et al., 2020).

The DE competencies of academic staff are becoming increasingly important for the future strategies of higher education institutions. For many educators, it is a challenging task to teach courses on the web. The quality of distance courses seems to be directly related to instructional design. In cases where suitable design guidelines cannot be found so as to teach distance courses, which are generally well-packaged content-wise but low pedagogy-wise, pedagogical problems emerge. Previous findings suggest that the difficulties faced by instructors, whether experienced or novice, related to web-based education stem from the complexity of the teaching situations and deficiencies in planning and organization (Rapanta et al., 2020). This requires the provision of pedagogical 
and technical guidance within the organizational framework. The preparedness of students and academic staff for DE, online pedagogy, corporate technology infrastructure, the organizational policy adopted, and support structures all affect the success of distance courses (completing the course, learning outcomes, etc.) (van Rooij \& Zirkle, 2016).

\subsection{Rapid Instructional Design (RID) in the pandemic period at higher education institutions}

During the pandemic, since universities had only a short time to transition to emergency remote teaching, the necessity to quickly digitize the contents and measurement tools emerged. On the other hand, there was a need to find quick solutions to the challenges posed by the online environment for academic staff and students. These urgencies called for the concept of Rapid Instructional Design (RID). Although RID and prototyping were initially considered for corporate education solutions, they can also be highly functional for educational institutions under certain conditions. Even though most instructional design models such as ADDIE, ASSURE, Dick \& Carey offer systematic guidelines, they typically require the design phases to be carried out in a linear/hierarchical structure in a time-consuming manner. Although it is accepted that they can also be applied for DE designs due to their generic structure, these models are especially useful for classroom learning. At this point, the concept of RID comes to the fore. It is based on by-passing instructional design stages that are not specific to certain educational situations. In RID, the aim is to focus on the design processes needed, and to avoid wasting time by removing unnecessary components/stages (Piskurich, 2009). While RID aims to shorten the duration of the instructional design, its main emphasis is to make the necessary educational arrangements to urgently overcome or solve a problem. From this aspect, the nature of RID arises from the problem.

The pandemic period made emergency remote teaching compulsory. The main purpose of the educational interventions carried out in this period was to make education accessible again. However, although it was envisaged to be a temporary period, it is possible that EDE initiatives carried out during the pandemic period will become permanent. They coincide with RID processes. In EDE, an established education system is given in a different or completely restructured form. Determining the curriculum is very important in emergency education. At this point, it appears that there are two trends. The first of these is the presentation of the curriculum as it is, but with a different method. The second is the presentation of the existing curriculum by adding new elements or reducing the subject density and revising it. Another distinguishing aspect concerns the timing of instructional design efforts. Contrary to the typical instructional design experience that includes activities that are planned to deliver education in a certain mode at the beginning of instruction, instructional design in times of crisis suggests the use of EDE and RID, which means the temporary shift of instruction to an alternative mode of delivery at any stage of education. 


\subsection{Rationale and objective}

With the announcement of COVID-19 as a pandemic in the Spring of 2020, the need for emergency remote teaching arose all over the world. Universities tried to complete their emergency remote teaching processes in the best way possible with the limited tools they had at their disposal. In fact, a decades-long "teach with technology" problem encountered by faculties had grown due to additional stressors and barriers along with the pandemic (Trust \& Whalen, 2020). Since this process vastly differs from face-to-face education in many respects such as needs, communication channels, and fast planning/transition, it is a worthwhile consideration to scrutinize how higher education institutions handled and managed the emergency remote teaching process organizationally. Identifying the challenges and problems faced by universities in this process will be useful for more effective handling of a highly possible similar event in the future. To advance the DE literature in this regard, the current academic endeavor aimed to undertake an in vivo examination of Turkish state universities' official websites in terms of their e-learning actions in the COVID-19 pandemic, and thereby to evaluate their preparedness for DE. More specifically, the scope of the current study encompassed revealing what actions Turkish higher education institutions took in EDE and how they adapted to this dynamic process in a limited timeline. In short, the study examined their status, with both pros and cons, in such a changeover phase due to the nationwide emergency. In this context, the problem statement of this paper was formulated as "What did Turkish state universities do at the beginning of the EDE transition process to smooth it?" To address this, the following research questions were created:

At the beginning of the EDE transition process, to what extent did Turkish state universities:

1) Have DE experience?

2) Become successful in managing the process?

3) Provide the information sources on their web pages?

4) Provide DE personnel and support?

5) Use the system solutions?

6) Provide guides and educate stakeholders?

\section{Method}

This section has been organized into subsections of research design, context of the study, process of the study, data collection tools, and lastly, data analysis.

\subsection{Research design}

As web-based environments have started to become a content-rich medium in which more than one individual can contribute, diverse methods have been developed for the analysis of digital contents and the extraction of meaningful information from 
this dataset. As one of these, content analysis is frequently utilized. The present research adopted quantitative content analysis as a research method. It is a technique used to examine any topic about human beings indirectly via the contents of their communications. It enables researchers to not only make inferences about human behaviors, but also to reveal and understand organizational patterns and insights (Fraenkel \& Wallen, 2006). The content analysis comprises the processes related to the examination of all kinds of texts in a systematic and repeatable way (Berelson, 1952; Krippendorff, 2018). Quantitative content analysis, on the other hand, can be defined as the assignment of communication symbols into numeric values based on predetermined rules and the examination of the relationships across the categories in a systematic way. Throughout the current study, quantitative content analysis was carried out using following the stages: (a) the preparation of research questions, (b) determination of relevant content to be analyzed, (c) formation of classification rules and training coders in this regard, (d) analyzing content according to classification rules, and lastly (e) measuring the reliability of coders (Riffe et al., 2019). These steps are shown in Fig. 1 and explained in the following sections.

\subsection{Context of the study}

Turkey has a highly centralized higher education system. The Council of Higher Education (YÖK) is a public institution that is responsible for checking, managing, and coordinating Turkish higher education institutions. Therefore, decisions of YÖK were significant in shaping the EDE process and, in turn, this study, especially the data collection element. Utilizing this authority with the aim of preventing the rapid spread of COVID-19, YÖK decided to suspend the learning/teaching process at the universities for three weeks as of 16 March 2020. Subsequently, a new decision was taken by YÖK to allow universities to continue their learning/teaching process through DE, which started the EDE process. Meanwhile, state universities in Turkey were not completely unaware of the notion of DE. They had already been teaching or preparing to teach at least some common courses called 5i courses (e.g., Principles of Atatürk and History of the Turkish Republic I, Introduction to English I, Turkish Language and Literature I) online before the pandemic occurred. Hence, they had experience of DE to a certain extent. In order to draw the boundaries of the

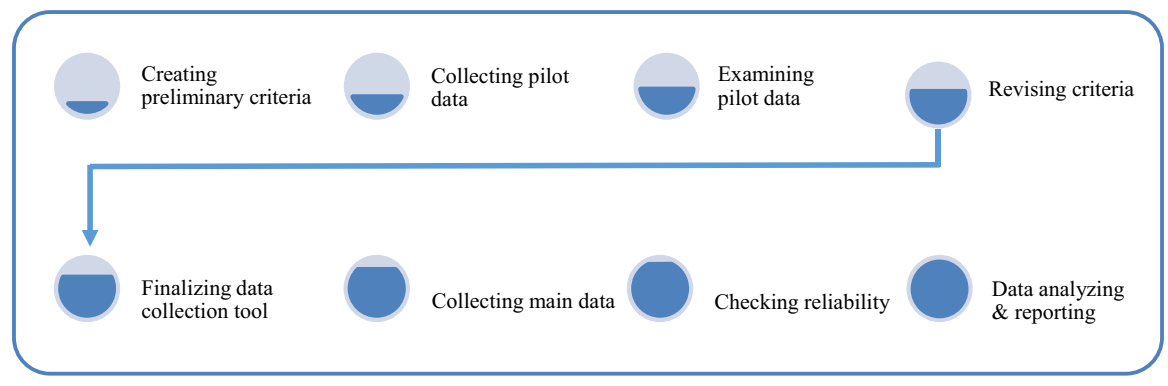

Fig. 1 Research process 
study well, this issue should be taken into consideration, especially in the interpretation of findings.

\subsection{Data collection tool}

A website review form prototype on which the coding rules were written was formed to help the coders (researchers of this study). To validate it, researchers randomly selected 15 universities. The preliminary form was trialed by each coder over five university websites. The purpose of the preliminary examination was to reveal and discuss conflicting decisions among the coders. In this pilot examination process, detailed explanations about the measurement criteria at hand were also provided to avoid conflicting decisions among coders. After that, the researchers discussed the limitations of the instrument, the different measures taken by the universities, and the situations that could not be examined. The criteria were reorganized in the light of the preliminary results and then the prototype reached its 27 -item final version.

\subsection{Process of the study}

The researchers first scrutinized the concept of emergency remote education, the measures regarding the COVID-19 pandemic in the world, especially in Turkey, and transformations in the education process during this phase. They then formed the research questions accordingly. Following this, the university statistics were accessed on the Council of Turkish Higher Education (YÖK) official website (yok. gov.tr). Statistical data of all state universities (129 in total) and their websites and subpages including their Center for Distance Education (CDE), continuing education center, computer center (also known as information technology center), and registrar's office were determined as the data source of the research.

The researchers conducted a pilot study in which they searched the official websites of 15 universities to check the suitability of the data collection tool containing classification rules. The purpose of the pilot study was also to test the practical accessibility of the predetermined criteria, as well as to improve criteria by addressing the prominent issues at the end of the preliminary research. The number of criteria, which was 17 before the implementation phase, increased to 27 following the pilot study (preliminary review). During this stage, all three coders were also trained on how to perform these classifications. Then, all state universities in Turkey were shared among the coders in alphabetical order. The coders manually searched the websites of the universities and accordingly entered relevant data into the data collection tool consisting of a 27-item cross-tabulation. The data on the existence of a $\mathrm{CDE}$, and, if any, its establishment date, the existence of the delivery of DE degrees such as associate, undergraduate, and graduate, and lastly the ratio of the number of DE students to the total number of students were obtained from the statistics on the official website of YÖK (YÖK, 2020a). In order to find the other data needed within the scope of the study, the coders rigorously searched the official websites of each university including the relevant subpages, such as announcements and notifications, news, events, IT department, continuing education center, student unit for 
disability (if any), CDE (if any), Learning Management System (LMS), exclusive pandemic web pages (if any) and so on. The data obtained as a result of this review were recorded on the data collection tool. In this way, each coder searched 43 Turkish state university websites, making 129 in total. Therefore, the sample reached the size of the data universe for it comprised all Turkish state universities. The data collection process was completed on 14 May 2020. After that, 18 randomly selected universities were cross-checked by coders different from those who had examined them previously, to test the consistency of the collected data.

\subsection{Data analysis}

Two universities were excluded from the data sources because they did not have any students and did not publish any measures about education in the pandemic process. The remaining data were analyzed using descriptive statistics such as percentage and frequency. In order to increase the reliability of the data collection process, researchers constantly exchanged ideas with each other in contradictory situations. In addition, the intercoder agreement was measured. In this regard, following the data collection process, the researchers conducted cross-examinations. Each coder cross-checked six universities previously searched by another coder. Thereby, a total of 18 universities underwent a double-check. As a result of the consistency check, the average agreement percentage between coders was calculated as $85.6 \%$, while the agreement percentages of the binary classification among coders ranged between $89.5 \%$ and $82.1 \%$.

\section{Findings}

This section includes a total of 27 findings obtained from data analysis. The findings are grouped thematically and presented under six subsections (also called themes) in line with the research questions. These subsections are DE experience, process management of DE, universities' information sources on the web, personnel and support, preferred system solutions, and, finally, guides and in-service training.

\subsection{DE experience (RQ 1)}

The availability and (if available) establishment date of CDEs, the existence of DE programs at different education levels, and the number of students enrolled in open and/or DE were addressed. This theme included eight criteria in total. According to the research results, while some 99 universities (77.95\%) had a unit like a CDE where distance education services were carried out, 25 universities (19.69\%) did not have such a unit. In three (2.3\%) universities, the CDE unit was established in 2020. Considering the DE experience by years, it was found that Turkish state universities had an average of 6.09 years of DE experience. Statistics for the educational degrees awarded through DE at universities in Turkey were examined and the findings obtained are presented in Table 1. 
Table 1 Distribution of DE degrees awarded at state universities in Turkey

\begin{tabular}{lll}
\hline $\begin{array}{l}\text { Degrees awarded by CDE in } \\
\text { Turkish State Universities }\end{array}$ & Frequency (f) & Percentage (\%) \\
\hline Associate degree & 37 & $29.13 \%$ \\
Undergraduate degree & 25 & $19.69 \%$ \\
Graduate degree & 45 & $35.43 \%$ \\
Undergraduate completion & 23 & $18.11 \%$ \\
Course/certification & 48 & $37.80 \%$
\end{tabular}

As reported in Table 1, 37.8\% ( $\mathrm{f}=48$ ) of universities offered at least one course/ certification program with DE. Following the certification programs, the most common types of DE program were graduate $(\mathrm{f}=45,35.43 \%)$ and associate degree ( $\mathrm{f}=37,29.13 \%)$ programs. When the DE programs were analyzed, it was determined that the number of universities that offered undergraduate $(f=25,19.69 \%)$ and undergraduate completion programs $(\mathrm{f}=23,18.11 \%)$ was relatively low.

This study also explored the ratio of students enrolled in associate, undergraduate, and graduate programs, which were delivered by distance or open education. The present academic work discovered that most universities $(f=73,57.48 \%)$ did not have any students enrolled in fully DE programs. Anadolu (99\%), İstanbul (77\%), and Atatürk (84\%) universities stood out in terms of the ratio of the number of students enrolled in open/distance education to those enrolled in formal education. Expressing these ratios in numbers, while the total number of students enrolled in distance or open education in İstanbul and Atatürk universities was above 200,000, this number was above three million for Anadolu university. In this sense, it can be postulated that these universities, Anadolu university, carry the burden of distance and open education programs at the nationwide level. Supporting how large these numbers are, the number of students studying with DE was less than 1,000 at 34 universities $(26.77 \%)$.

\subsection{Process management of EDE (RQ 2)}

The transition time to EDE and the unit providing an EDE service during the pandemic period were touched upon under this research question. There were two criteria under this theme. After the declaration of COVID-19 as a pandemic in the country, institutions started to take various precautions. Educational institutions suspended face-to-face education after 16 March 2020. Then, it was decided to carry out the process remotely with DE. Universities were provided with partial flexibility on this decision. In Fig. 2, the transition times of universities to the EDE process are visualized.

The majority of the universities $(f=71,55.91 \%)$ started the EDE process on 23 March 2020, one week after the suspension decision of YÖK. 25.98\% ( $f=33)$ of universities were ready for remote teaching two weeks later and $16.54 \%$ completed the transition after three weeks. Accordingly, three weeks after 23 March 2020, all 


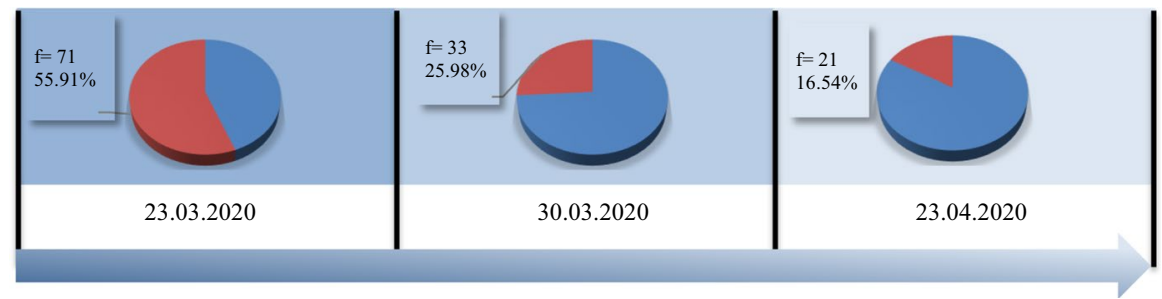

Fig. 2 Transition time to EDE

universities with the exception of two (1.57\%) where there was no explicit information found regarding the transition date had started EDE.

The researchers went through the university website as a whole in order to reveal by which units the EDE activities were undertaken or contributed. This review was carried out in line with the information and links from the university's main web page or specified information subpage. The researchers concluded that these units contributed to the organization of EDE activities if they found instructions, announcements, and textual/audiovisual guidelines, materials and tools that catered for academic staff and students regarding the EDE process on their web pages. The unit that coordinated the EDE services during the emergency remote teaching process is given in Fig. 3.

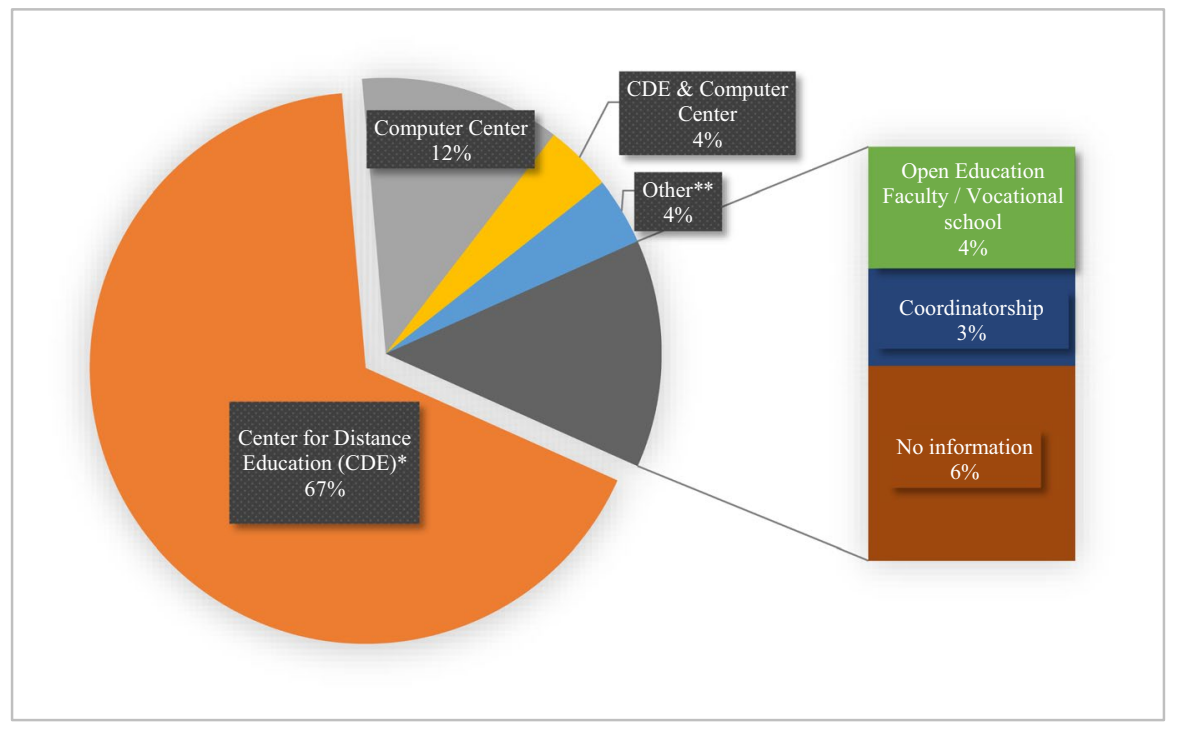

Fig. 3 The unit that coordinated the EDE services during the emergency remote teaching process. *Units such as Open and Distance Learning Center, Research and Development Unit for DE, Distance and Computer Teaching units, etc. were regarded as the CDE. ** Other: Continuing education center, Instructional technology support unit, Center for Advancing Learning/Teaching, etc. 
Most universities ( $\mathrm{f}=102,80.31 \%$ ) have CDE or similar units. During the pandemic period, these units have played a leading role in managing the EDE process such as providing the technical and pedagogical infrastructure for the emergency remote teaching. As seen in Fig. 3, emergency remote teaching activities in higher education were mainly coordinated by CDEs ( $f=85,67 \%$ ). In addition to CDEs, computer centers have also provided support in the EDE process. It should be noted here that although a single unit has come to the fore in most universities, several units such as digital transformation offices, computer centers, student registrar's offices, and instructional technology support offices have contributed directly or indirectly to the EDE process. In this regard, five universities (4\%) coordinated the EDE process with the collaboration of $\mathrm{CDE}$ and the computer center. At five universities ( $f=5,4 \%$ ), existing DE faculties or vocational schools took an active role in remote teaching. Since there were no CDEs in four universities $(3 \%)$, coordinatorships were established to manage the EDE. Lastly, no information was available on which unit managed the EDE process in eight universities $(6 \%)$.

\subsection{Universities' information sources on the web (RQ 3)}

University websites were searched in terms of pandemic-specific arrangements, language support, and accessibility in order to assess the facilitation of the information delivery throughout the pandemic period. This theme covers three criteria. An exclusive web page for the pandemic period, foreign language support on a CDE web page, and accessible CDE web pages are reported in Table 2.

As of the completion of the data collection, it was found that 56 universities $(44.1 \%)$ in total prepared exclusive web pages pertaining to EDE in the pandemic period. Others $(55.9 \%)$ preferred to publish announcements over the existing unit web pages. The examination of language support determined that only 10 universities published websites in foreign languages, 22 universities had limited foreign language support, and 95 universities did not prepare any web pages specific to the pandemic period for international students (see Table 2). As a result of the examination of accessibility actions for students with disabilities, it was found that three universities offered the required support and another three universities limited support for

Table 2 Statistics about the universities' EDE information sources on the web

\begin{tabular}{lllc}
\hline Criterion & Category & Frequency (f) & Percentage (\%) \\
\hline An exclusive web page for the pandemic period & Yes & 56 & 44.10 \\
& No & 71 & 55.90 \\
Foreign language support on CDE web page & Yes & 10 & 7.87 \\
& Limited & 22 & 17.32 \\
& No & 95 & 74.80 \\
Accessible CDE web page & Yes & 3 & 2.36 \\
& Limited & 3 & 2.36 \\
& No & 121 & 95.27 \\
\hline
\end{tabular}


disabled students. Some 121 universities (95.27\%) did not make any customizations for disabled students on their websites and gave no institutional announcements in this regard.

\subsection{Personnel and support (RQ 4)}

Under this theme, the existence of an instructional technologist who offered technological and pedagogical support in the CDE team, support structure and channels, open courseware material support, and a software repository, six criteria in total, were addressed. Table 3 displays the findings related to this examination.

As Table 3 shows, $45.67 \%$ of the universities employed at least one staff member educated in instructional design in their CDEs, whereas $35.43 \%$ of universities had no instructional technologist within their CDE organizational structure. Additionally, while a little less than three-quarters of the universities $(73.23 \%)$ coordinated support services from a single center, a little more than a quarter $(26.77 \%)$ organized these services on a department basis, that is, in a distributed manner. Universities that adopted distributed execution of support services attempted to provide rapid support and facilitate coordination within departments. In addition, units responsible for DE provided instructional and technical support to both academic staff and students through synchronous and asynchronous communication channels. To give detail, it was ascertained that $81.1 \%$ of universities used asynchronous methods (e-mail, problem report form, etc.), while $68.5 \%$ used synchronous communication tools.

Table 3 Support Staff and Services in CDEs

\begin{tabular}{llll}
\hline Criterion & Category & Frequency (f) & Percentage (\%) \\
\hline Instructional technologist in CDE & Yes & 58 & 45.67 \\
team & No & 45 & 35.43 \\
& No data & 24 & 18.90 \\
Unit-based DE support Structure & Yes & 34 & 26.77 \\
& No & 93 & 73.23 \\
Asynchronous DE support & Yes & 103 & 81.10 \\
\multirow{5}{*}{ Synchronous DE support } & No & 24 & 18.90 \\
& Yes & 87 & 68.50 \\
Open courseware material support & No & 40 & 31.50 \\
& Yes & 6 & 4.72 \\
& Partially Yes (Closed to Outside) & 10 & 7.87 \\
Software repository & Partially Yes (Limited Material) & 5 & 3.94 \\
& No & 106 & 83.46 \\
& Yes & 50 & 39.37 \\
& Limited & 21 & 16.54 \\
& No & 56 & 44.09 \\
\hline
\end{tabular}


In relation to the open courseware systems of universities, $83.46 \%$ of universities did not have an open courseware system. Some universities granted limited access to open courseware platforms in a way that covered only several departments or courses, while others had a semi-closed courseware platform, which was only accessible to the members of the relevant institution. Finally, the software repository status of universities was investigated. Some $39.37 \%$ of universities $(f=50)$ offered a comprehensive software repository to their members, whereas $16.54 \%$ ( $f=21)$ had a limited software repository to cover only a few of the operating systems, offices, and anti-virus software. However, almost half of the universities (44.09\%) did not provide licensed software to their members.

\subsection{Preferred system solutions (RQ 5)}

To address this research question, the learning management and web conferencing systems preferred by the universities were examined. In other words, under this theme, there were two criteria that aimed to identify the technological infrastructure. As a result of the research, it was ascertained that 27 universities benefited from two different LMSs and six universities benefited from three different LMSs at the same time.

As seen in Fig. 4, 37.8\% of universities $(f=48)$ preferred Moodle, which was found to be the most popular open-source LMS. In second place, the LMS named ALMS (35.43\%) developed by a local software company was preferred. In third place was Google Classroom ( $\mathrm{f}=16,12.6 \%$ ), an LMS solution available free during the pandemic period. Several universities ( $\mathrm{f}=10,7.87 \%$ ), on the other hand, continued the EDE process through existing student information systems by adding some

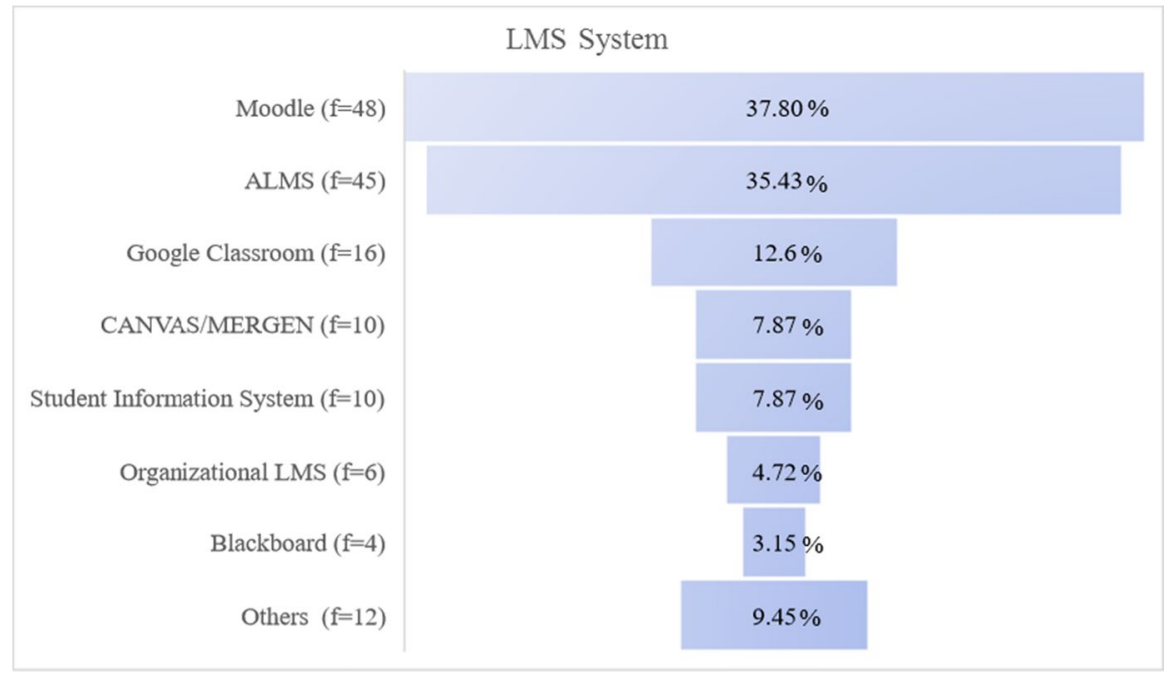

Fig. 4 Preferred learning management systems 


\begin{tabular}{|c|c|}
\hline \multicolumn{2}{|c|}{ Web Conferencing Systems } \\
\hline Perculus $(f=36)$ & $28.35 \%$ \\
\hline Adobe Connect $(\mathrm{f}=28)$ & $22.05 \%$ \\
\hline BigBlueButton $(f=27)$ & $21.26 \%$ \\
\hline Zoom $(f=23)$ & $18.11 \%$ \\
\hline Google Meet/Hangouts $(\mathrm{f}=17)$ & $13.39 \%$ \\
\hline Microsoft Teams $(\mathrm{f}=17)$ & $13.39 \%$ \\
\hline Other $(\mathrm{f}=11)$ & $8.66 \%$ \\
\hline
\end{tabular}

Fig. 5 Preferred web conferencing systems

new features such as content sharing, homework management, discussion, and exam management.

Another important element of technological infrastructure used in the EDE process was web conferencing systems. Those preferred by universities are presented in Fig. 5. The most prominent were Perculus (28.35\%), Adobe Connect (22.05\%), and BigBlueButton (21.26\%). While BigBlueButton is an open source and free system, other preferred solutions are offered by commercial companies as ready to use.

Table 4 Guides and in-service training

\begin{tabular}{llll}
\hline Criterion & Category & Frequency (f) & Percentage (\%) \\
\hline Academic staff text guide & Yes & 92 & 72.44 \\
& No & 35 & 27.56 \\
Academic staff video guide & Yes & 86 & 67.72 \\
Student text guide & No & 41 & 32.28 \\
& Yes & 100 & 78.74 \\
Student video guide & No & 27 & 21.26 \\
& Yes & 78 & 61.42 \\
Material production guide and support & No & 49 & 38.58 \\
& Yes & 32 & 25.20 \\
& Limited & 8 & 6.30 \\
In-service training on DE & No & 87 & 68.50 \\
& Yes & 23 & 18.11 \\
& No & 104 & 81.89 \\
\hline
\end{tabular}




\subsection{Guides and in-service training (RQ 6)}

Under this theme, there are a total of six criteria addressing EDE orientation and instructional design guides (i.e., academic staff and students, and material design guides) and in-service training on DE. The findings of this review are summarized in Table 4.

This scholarly work indicated that a considerable number of universities did not offer any text or video guidance to their stakeholders. Besides, the majority of the universities did not create a material production guide for academic staff $(68.50 \%)$ (i.e., uploading course material, creating synchronous lessons). Lastly, a limited number of universities offered in-service training (18.11\%) to academic staff on DE pedagogy such as interactive digital material development and e-measurement.

\section{Discussion}

The discussion of the research questions is organized in the same order as they were presented in the findings section.

\subsection{DE experience (RQ 1)}

Availability and establishment dates of CDEs, the existence of DE programs for different education degrees, and the number of students enrolled in DE were probed in order to reveal the extent to which Turkish state universities had DE experience. First, it was found that few universities had such a unit before 2010. Since then, the interest of higher education institutions in DE has increased rapidly in the last decade. Apart from this, the institutional initiatives towards DE-based undergraduate programs in higher education settings was found to be low compared to course/ certification, associate, and postgraduate degree programs. In short, it was seen that a limited number of universities had institutional experience of DE, while a significant number of universities did not have experience of DE prior to the pandemic period. Indeed, the study conducted by Bilgiç and Tüzün (2020) reported that less than half of Turkish universities opted for DE programs in the pre-pandemic period, and also the number of institutions providing undergraduate programs was considerably lower compared to those offering associate and postgraduate programs. Pertaining to the number of students enrolled in $\mathrm{DE}$, the universities were seen to conduct DE activities in the context of lifelong/continuing as well as formal education. It was apparent that the majority of DE students were enrolled in open education. At this point, only a small number of universities (three to be exact) had undertaken the burden of open education in higher education settings. Little seems to have altered in the years since Bilgiç and Tüzün (2020) stated that the number of students enrolled in open education programs as of 2017-2018 corresponded to about a quarter of students enrolled in formal higher education programs, although they were enrolled only at three universities. This situation in DE programs is very similar to that in other countries such as China, Japan, and India (Jung et al., 2011). 
The DE technologies are being adopted by an increasing number of higher education institutions, and public and private organizations (Alsabawy et al., 2016). Similarly, the demand for distance education is growing worldwide. Considering the ratio of universities offering DE at the level of associate and undergraduate degree was about one in five in 2011 (Ateş, 2014), it was concluded that the interest of higher education institutions in DE rose regardless of the increase in their number (Günay \& Günay, 2011). Similarly, the number of higher education students taking online courses in the United States (US) increased approximately 5.5 times between 2000 and 2012 (Ortagus, 2017). As of 2014, approximately one in four of all undergraduate students in the USA took online courses; while, as of today, approximately one in every three (29\%) students are having a DE experience (Bilgiç \& Tüzün, 2020; Fischer et al., 2020). With the spread of MOOCs and open education resources, in particular, distance learners in higher education are expected to overtake on-campus learners in the future (Palvia et al., 2018). As another example, some residential higher education institutions in China were encouraged to conduct DE programs in 1998. The number of these universities, which exceeded 30 in 2000, had reached 68 by 2008 (Li, 2018). With this reform, the number of DE students approached three million. This has continued to increase to date, and has accelerated with the opening of the Chinese Open University established in 2011. Emergency DE initiatives conducted during the pandemic period are likely to shape interest in DE on the institution, academic staff, and learners' sides. Turning back to the Turkish context, for example, YÖK allowed universities to teach up to $40 \%$ of their face-to-face courses using online mediums (YÖK, 2020b).

\subsection{Process management of EDE (RQ 2)}

The transition time to EDE and the unit providing the EDE service during the pandemic period were discussed under this theme. Generally speaking, the transition time to EDE at universities was rather short considering the sudden emergence of COVID-19. In other words, EDE was quickly implemented in Turkey without adequate preparation due to the nature of the problem. Despite its familiarity, most universities had deficiencies in their readiness to support full e-learning during the pandemic period (Coman et al., 2020). It appears that CDEs contributed significantly to complete the process of transition to EDE in a short time span, such as one week (23 March 2020). The fact that emergency educational activities were carried out predominantly by CDEs supports this argument. Aside from this, it was discovered that more than three-quarters of CDEs at universities came into service in the past decade. Higher education institutions resorted to DE with the purpose of responding to the ever-increasing demand for education. These centers not only offer fully distance programs, but also teach common courses on the web environment. They contributed to the establishment of the technical infrastructures required at universities and facilitated students and academic staff to gain familiarity with DE. In the absence of these centers, the technological infrastructure required for DE, especially for emergency educational activities, was supplied through the computer centers. Similarly, in other countries, the EDE transition has taken place under the 
coordination of existing centers specialized in the field of DE, learning, and teaching (Singh et al., 2021).

\subsection{Universities' information sources on the web (RQ 3)}

Within the scope of the study, the researchers also investigated whether universities had exclusive web pages for the pandemic period, whether COVID-19-related announcements were published in a foreign language, and whether they were accessible. Many documents, links, and videos, such as announcements about health precautions against COVID-19 and guidelines about the use of LMSs, were typically published by universities in this process. Universities distributed this information and documents through different communication channels. Some published the necessary information through an exclusive web page in order to integrate distributed information and documents to better explain the measures taken regarding this extraordinary process and educational transformation. These specialized web pages, which were more useful and compact compared to the university or CDE home pages, enabled students and academic staff to access the information/instructions (DE guides, videos, announcements, instructive materials, etc.) more easily.

In this mandatory transition period, more than half of the universities announced the guidelines on their main web pages in a conventional way. Yet, useful and practical university websites are crucial for students to use DE systems efficiently (Arif et al., 2017; Mutlu-Bayraktar, 2016) because websites are the most important media tools that enable organizations (i.e., academic institutions) to communicate with their target audience (e.g., potential, enrolled, and graduate students, academic and support staff, parents, and other stakeholders) (Bringula, 2013). Universities' websites mainly serve as a portal that contains corporate contents (policy, announcements, promotions, news, tenders, and cooperation, etc.) digital resources, and contents. The heterogeneity of user profiles directly affects the design and use of websites (Banati et al., 2006; Katsanos et al., 2010). Therefore, it is a reasonable approach to provide specialized web content in a distinctive manner in order to facilitate access to relevant information for students and academic staff and to create information communities.

It was found that in three out of every four universities foreign language support was not provided on the web pages of CDEs. Age, physical and cognitive health status (disorders), and cultural characteristics/backgrounds of users affect students' web usage (Bringula, 2013). However, globalization in education and the increasing mobility of international students require universities to offer multiple language options in their teaching. This is because providing foreign language options in education is an important tool for reaching international students, realizing international collaboration, and supporting the development of local students' language skills (Callahan \& Herring, 2012). Callahan and Herring (2012) stated that English being the primary foreign language in higher education is about institutional prestige and promotion as much as students' career development. Aside from this, universities determine the type of their second and third foreign language support according to the distribution of their foreign student populations affected by their 
geographical locations. In Turkey, the most common foreign language supported in education is English. On the other hand, it seems that this situation was not a priority in EDE design in Turkey. This is considered to negatively affect the accessibility of educational content and announcements regarding DE. This situation might also be explained by the fact that the relevant universities do not have foreign students or that these students know Turkish at a basic level.

The extent to which disabled students are considered in this process is another research question addressed in this study. According to the results, the overwhelming majority of universities did not take accessibility precautions for students with disabilities. As this attracted a great deal of attention, YÖK published an announcement on 5 May 2020 and advised universities to take necessary measures for disabled students. It is evident that there are various physical barriers in DE, especially for disabled students. For instance, time spent on learning (especially in synchronous lessons), technical problems, insufficient accessibility tools (simultaneous translations, voiceovers, navigation tools, font enlargement, etc.) are important barriers in DE (Alsadoon \& Turkestani, 2020). The starting point of DE is to enable individuals to continue their education in accordance with their own lifestyles (Lee, 2020). However, the efforts of higher education institutions providing DE to "reach more people with high quality and low cost" constitute a strategic motivation stemming from competitive conditions rather than social responsibility (Murphy, 2013). The most important strategic motivation elements towards DE include increasing the potential of the institution and its recognition, gaining experience in DE, benefiting from national and international funding, and contributing to national economic and social benefits (Lane, 2012; Lee, 2020; Murphy, 2013). Although this situation creates a socio-political incentive to expand the participation of different student groups (including those who are at risk/disadvantaged or with different cultural backgrounds) in DE, it does not seem sufficient. For this reason, it is necessary to focus on the diversity of students as much as the number of students participating in DE activities.

\subsection{Personnel and support (RQ 4)}

In instructional design and the DE process, support is a pivotal element. In this regard, the existence of an instructional technologist in the CDE team, a DE support structure, and the availability of open courseware material and a software repository was examined. In this research, first, the human resources of the universities were examined. This study showed that approximately half of the universities were found to employ instructional technologists within their CDE. Instructional technologists were considered to be experts who had graduated from departments related to computer and learning sciences. In their model regarding institutions' e-learning readiness, Demir and Yurdugül (2015a) laid stress on human resources. Hence, providing appropriate support structures for students and academic staff is crucial for the success and sustainability of DE programs. Supporting DE course development endeavors and overcoming technological barriers are mandatory for the organizational structure to be successfully designed for DE (McGee et al., 2017; Tüzün, 2001). 
Bilgiç et al. (2011), in their study on CDE experts and academic staff, found that they need pedagogical and technical support on the online environment, and had difficulties, especially in e-content preparation, selection/application of appropriate pedagogies, use of DE systems, time management, student assessment, and feedback mechanisms. Although learning outcomes in DE settings are, to some extent, related to learner characteristics (metacognition, motivation, and pre-competencies, etc.), pedagogy-wise well-planned course designs contribute significantly to learner success by increasing participation, collaboration, and communication (Czerkawski \& Lyman, 2016).

Instructional design is a roadmap that enables instructional objectives to be achieved with the highest probability. However, many academic staff, who have to teach their courses through the web, cannot find appropriate guidelines. This resulted in the emergence of electronic course pages equipped with digital content (Tüzün \& Çınar, 2016). The delivery of courses with DE might become a rather chaotic effort, especially for academic staff who are used to teaching in the classroom and do not have distance or blended education experience. Regardless of the DE experience of academic staff, all higher education courses, excluding some applied sciences, were given through the web during the pandemic period. Instructional design of DE is a versatile and complex process that requires pedagogical, technical/technological, and online communication competence. It is unlikely that these skills can be found in one individual. In the last quarter-century, important changes and trends have occurred in learning sciences (West et al., 2017). This change is even more dynamic for instructional technologists. They are important mediators in providing the support that subject-matter experts need, especially in DE practices, which are in rapid technological evolution. Although the pandemic-related emergency education process necessitates a full but temporary transition to DE, in the long term it can make significant contributions to shaping DE activities through appropriate technical and pedagogical support structures.

This academic work came to the conclusion that about three out of four universities opted for central support services. This is likely to be due to the appeal of professionalization partially resulting from a pre-existing central system. However, Bilgiç and Tüzün (2020) reported that the reaction time of central support units to students' needs and requests is relatively long. Therefore, the non-central supply of support services have some advantages in responding to stakeholders' questions and requests more quickly and effectively. Indeed, department-based requests appear to help pave the way for the formation of a department-specific common knowledge/ experience. Thus, identifying department-specific thematic support elements can render institutional reactions more dynamic.

As for the findings in relation to the communication channels adopted by universities, they indicated that asynchronous communication channels were preferred more than synchronous communication channels for support by universities. Of course, considering the connection problems, the diversity of support channels, whether synchronous or asynchronous, is of great importance. For this reason, CDEs provided support services for students and academic staff through asynchronous means, such as e-mail and forms, and synchronous communication channels such as chat and call centers during the emergency period. Nevertheless, students need more 
interactive support structures for DE (Aksal et al., 2016). Therefore, more emphasis should be placed on synchronous communication channels in order to produce faster solutions to problems, especially technical issues.

A salient finding of the current study showed that a very limited number of universities in Turkey offered an open courseware platform and a small number of universities that support open access offered access within the institution, that is, it is not open to the public. This hinders the opportunity to access open course materials free of charge and is against the worldwide trend that open learning resources are increasingly popular in DE (Zawacki-Richter \& Naidu, 2016). Copyright obligations are among the main obstacles to the full implementation of the institutional repository including open courseware materials (Ming, 2020). Many top-tier universities in the world (MIT-OpenCourseWare, Carnegie Mellon University-Open Learning Initiative, etc.) have made their courses and learning resources open access. Beyond institutions, these resources undertake an important mission in closing the learning gap among students on a global scale and ensuring equal opportunity (Richter \& McPherson, 2012). It also offers students the opportunity for self-development in different academic disciplines according to their interests. To remedy this problem, with the participation of many universities, the consortium of open course materials was formed by the Turkish Academy of Sciences in 2007. However, there is a limited number of open course materials in the archive of this consortium since the distance learning course contents of most universities are not open access.

Another criterion investigated in the scope of the study was the availability of licensed software offered by universities to their members. According to the results, nearly half of the universities could not offer licensed software repositories. On the one hand, licensed software plays an essential role in digital instructional material production. The institutional software repository enables academic staff and students to easily access the computer programs they need. These software repositories often include productivity tools, academic programs, and utility software. In today's world, all universities aim to enhance academic productivity and quality, yet to be able to attain this, academic staff and students need licensed software. After all, one needs a hammer to nail. On the other hand, the lack of licensed software is likely to result in the use of pirated software by both parties, which may give rise to legal liability for universities. Being aware of these situations, universities appear to have struggled to structure their institutional software repositories. To speculate, financial issues might have played a critical role in not permitting universities to found rich licensed software repositories.

\subsection{Preferred system solutions (RQ 5)}

Another question addressed in this research was the examination of DE technologies such as LMSs and web conferencing systems used by universities in the process of EDE. The present study yielded the finding that an LMS was the main tool used to ensure students' access to learning resources and in-class activities in DE during the pandemic period. This finding is also in agreement with relevant studies in the literature (Pinto \& Leite, 2020; Rhode et al., 2017; Sandars et al., 2020). Corroborating 
this, Demir and Yurdugül (2015a) came to the conclusion that ICT infrastructure has a place in every model designed for assessing institutions' preparedness for DE. Therefore, in any DE design, the instructional and technical components must be dealt with in mutual interaction even for an emergency state (Tüzün \& Çınar, 2016). With the development of ICT tools, learning environments in which knowledge and experience are gained have evolved significantly (Rejón-Guardia et al., 2020). The use of these tools for educational purposes, especially DE, has gradually increased. Examples of DE environments are LMSs, web conferencing applications, content repositories, forums, wikis, social networks, video sharing sites, cloud-based collaborative working tools, instant messaging applications, blogs, and virtual worlds. In particular, LMSs have been an important springboard in organizing various learning resources in a fast, flexible, and effective way that everyone can access at any time and from anywhere. In addition, they have made it possible to gather other DE environments under a single roof. It was seen that the rate of adoption and use of LMSs were quite high in DE.

When the DE systems of the universities were analyzed, it was seen that a considerable number of them preferred open-source LMSs or other free solutions and very few had made an effort to develop one. For instance, more than one-third utilized Moodle. Concurring with this, Moodle was found to be one of the most widely preferred open-source LMSs in EDE (Pereira \& Guerreiro, 2021). Yet, a similar tendency towards open-source solutions did not apply to video conferencing software. Among those used in the process, only BigBlueButton whose penetration rate corresponded to less than a quarter was open-source software. Using ready-made systems instead of building the necessary technical infrastructure from scratch makes it possible to cover great distances with small arrangements, especially in rapid designs for EDE. Besides, it is important to minimize the use of resources such as development time, effort, and cost. Being easy to use and functional is an issue to be considered as the design of highly usable systems has an impact on the users' intentions to continue DE (Chiu et al., 2005). In summary, universities preferred to receive more professional support for the video conferencing features. Limited timeframe for preparation, the effort and cost of the installation of open systems for video conferencing systems, and the high bandwidth requirements are considered to play key roles in this tendency.

The results indicated that while some universities carried out the EDE process only asynchronously, most implemented synchronous lessons as well in an effort to leverage quality. However, despite the increasing use of ICTs, higher education institutions could not meet the users' expectations in this effort (Dhawan, 2020). This appears to highlight the uses rather than tools (Garg et al., 2015; Sakala \& Chigona, 2020). The lack of familiarity of potential users with these technologies, problems in the use of new tools, resistance to change, the lack of out-of-institution usage, and integration needed with other tools to support users' learning are some of the barriers in the use of DE technologies (García-Peñalvo et al., 2011). It is frequently emphasized that the use of LMSs and video conferencing tools alone does not change the role of students as passive recipients of the content. Therefore, the production and sharing of content require more student engagement, interaction, 
flexibility, autonomy, the use of student-centered pedagogies, and a flexible role for academic staff.

\subsection{Guides and in-service training (RQ 6)}

Finally, the last research question addressed whether or not universities created text and video guides for academic staff and students. Furthermore, material production guidance and in-service training on the DE process were discussed under this theme. First, it was found that approximately a quarter of universities did not provide any guides. In relation to this, Demir and Yurdugül (2015b) emphasized that higher education institutions' preparedness for DE is directly affected by academic staff's preparedness, particularly their self-confidence. In this context, any kind of guide for academic staff is likely to play an important role in promoting their selfconfidence about DE to a satisfactory level. Apart from this, it was also determined that universities offered text guides rather than video guides to academic staff as well as students. This is probably because of the high initial cost of instructional video production. This seems plausible given the nature of RID. How guidelines should be presented to make better use of cognitively diverse students is an important research topic. Although each element of content contains its own quality, the presentation modality or technique affects the learning performance. Yet, although text-based guides or instructions have been mainstreamed widely in e-learning settings, a recent study showed that instructional videos are more effective than textbased equivalents in terms of learning performance (van der Meij \& van der Meij, 2014). Besides, video mode (picture-in-picture, lecture capture, and voiceover videos), namely organization of multimedia elements, also has an effect on learning performance in the e-learning settings (Chen \& Wu, 2015; Kokoç et al., 2020). On the contrary, pertaining to student guides, text-based materials are more accessible because video-based guides consume much more internet data, for which students have to pay GSM operators in rural areas owing to the lack of broadband internet infrastructure. Apart from this, two more points draw attention regarding the guides. The first is that some universities opted to use existing videos produced by LMS companies rather than creating new videos specific to the situation. This was probably due to time limitations imposed by the fast transition. The second is that the guides for students were prepared to explain access to LMS and synchronous lesson systems for mobile devices. The obvious reason behind this was the common use of mobile phones among students to attend courses and to complete assignments.

One of the most important components of the DE process is the instructional design and material development. Unfortunately, nearly three-quarters of universities did not prepare any guide to facilitate this. The instructional design of DE requires many new knowledge and design skills. However, by assuming that the academic staff have the knowledge and skills on this issue, institutions ignored the support needed for instructional design in DE (Power, 2009). For this reason, universities must prepare specialized guides for development of materials instead of general guides in order to better meet the needs of academic staff and students. 
The results yielded that the overwhelming majority of universities did not arrange any in-service training to prepare their stakeholders for DE. On the one hand, university students' motivation for using DE is relatively low (Çınar et al., 2021; Yurdugül \& Demir, 2017). On the other hand, academic staff lack self-confidence in using DE and need in-service training (Demir, 2015). In the light of these findings, the failure of universities to arrange any in-service training for their members and to cultivate the DE competencies of both academic staff and students as the EDE process progresses seems problematic, since, in order for DE applications to achieve their purpose, both academics and students should be well informed and their competence in technology should be increased (Altınay et al., 2019).

\section{Final remarks}

Despite the growing research trend in EDE, there is limited evidence of what factors/dynamics lie behind successful EDE system integration, and how the EDE principles should be included in the policies of educational institutions. In this context, the present study provides important information about how higher education institutions in Turkey managed their activities in the pandemic period in the context of EDE. The findings of this study could illuminate ways to improve the sustainability of DE endeavors that were resorted to as a mandatory solution during the pandemic. In this study, the problems faced by all Turkish state universities in the EDE process were identified based on the data collected from their official websites and YÖK's statistics. Accordingly, some suggestions were given to make the next highly possible EDE process more efficient and effective.

The findings of the current study showed that even though more than three out of four universities had a CDE or a similar unit before the start of the pandemic, the primary problem they encountered was still the lack of technical infrastructure. This corroborated Ahmed and Opoku's (2021) findings. This might be attributed to the fact that more than half of these CDEs were either inactive or active with a limited number of programs and students. As an alternative explanation, this situation is likely to stem from the speed of the transition to EDE and the sheer number of students taught with DE. Regarding the speed of transition, the fact that more than half of the universities started the EDE process on 23 March 2020, a week after YÖK's announcement of mandatory transition to EDE, might have also contributed to this result. Universities strived to solve the prevalent infrastructure problem in different ways by considering the contexts in which they were located. Of the problems faced by universities in the EDE process, CDE infrastructure attracts attention. Universities with a strong CDE infrastructure carried out the EDE processes through professional LMSs such as Blackboard or Advancity ALMS. The universities that had only recently established their CDEs resorted to using completely free LMSs such as Google Classroom or MS Teams and video conferencing systems such as Google Meet, Zoom, and BigBlueButton, as a fast and temporary solution. Another lack of technical infrastructure that stood out in the EDE process was that most institutions did not have any open course materials and software tools. The absence of open course materials made it difficult for students to access source materials, whereas 
the absence of a software repository obstructed access to the software that was critical for the content and homework preparation in the EDE process of both students and academic staff. Regarding the internet infrastructure problem, mobile GSM operators in Turkey offered free mobile internet packages to university students as a solution to the lack of connectivity problem. However, these mobile internet packages were insufficient due to the intensive data transfer requirements, especially in synchronous courses. Theoretically speaking, such efforts to support synchronous courses might be regarded as an attempt to reduce transactional distance (Moore, 1993), which occurs as a result of physical distances associated with both DE and the pandemic. In brief, this study concluded that these technical infrastructure problems dramatically limited the efficiency and effectiveness of EDE.

A striking conclusion of this study is that more than two-thirds of universities did not offer their academic staff in-service training and material development support in DE. It is also worth noting that about a quarter of the universities did not prepare video and text guides to assist their members with technical issues in LMS, synchronous lesson systems, etc. It was also found that some universities whose guides were accessed in this regard shared the links of generic videos prepared by commercial companies instead of producing new situation-specific videos. These two situations may be partially related to the lack of competent staff to procure support at universities as well as limited preparation time and technical infrastructure. This result is compatible with the finding of the present study that a significant number of the universities did not have an instructional technologist in their CDE teams. This situation can be explained partly by the absence of an active department that trains instructional technologists in corresponding universities. The fact is that DE and instructional design falls into the specialty of instructional technologists. Indeed, there is a multi-disciplinary department at universities called Computer Education and Instructional Technology (CEIT) in which instructional design, online content development, and DE courses are taught theoretically and practically. In this context, the EDE and RID process experienced due to the COVID-19 outbreak revealed the importance of the CEIT departments and the other units where competent personnel in the aforementioned information domains are trained.

After analyzing the results of EDE carried out during the pandemic period, YÖK decided to allow universities to perform their instructional programs with the DE method in the range of 10 to $40 \%$ of course content for the future (YÖK, 2020b). The interpretation of this is that the applications of universities in the EDE process are not intended to be limited only to the pandemic process. That is to say, YÖK found the affordances of DE adequate. In fact, EDE provided universities with the opportunity to experience the advantages of DE such as flexibility and access from anywhere and at any time. Besides, this decision might be considered to be a vital step in the preparation of higher education institutions for DE, if the adverse effects of the pandemic continue.

In a nutshell, higher education institutions coped with some serious problems in the transition to EDE, but they generally overcame these problems and completed the education semester successfully. This is because YÖK and universities took some quick and accurate actions at this point. Of these, YÖK tried to solve the online content problem by setting up a free online environment supported by the 
online course materials of Atatürk, İstanbul, and Anadolu Universities, which are fairly experienced in DE compared to their associates. As another example, it was concluded within the scope of this study that the CDE pages were not accessible for disabled students and academic staff. In remedying this deficiency, YÖK informed all universities on 5 May 2020 that they should take measures to solve the problems disabled students experienced in the EDE process (YÖK, 2020c). In addition to these points, other suggestions for action by the relevant institutions for improvement of the quality of EDE are addressed in the following section.

\section{Suggestions and limitations}

The EDE process experienced as a consequence of the COVID-19 outbreak should be considered as an opportunity to improve the DE infrastructures of universities, the instructional design of distance courses, and the digital competencies of students and academic staff. For this reason, the findings and suggestions of the current study gain importance. In this context, several suggestions arise within the scope of this study. First, although the 2019-2020 Spring term has been successfully completed by all higher education institutions, universities with little or no experience of DE are strongly recommended to receive instructional mentorship in addition to infrastructure, technical, and content support from universities experienced in DE. It is also recommended that universities open their educational infrastructure to all students from different universities by collaborating with each other on technology access. Moreover, universities faced some problems with providing the necessary in-service training and support to their members about DE course design, especially the instructional design of DE. At this point, academic staff can be guided by sharing sample course designs and contents. To this end, it is noteworthy that some universities created various guides and provided support services. Therefore, universities seem to have concentrated on this matter to meet the demands in this direction. Besides, when creating DE course designs, the important role of interactive elements such as in-class discussion, synchronous lesson sessions, and student feedback, should be considered to reduce the transactional distance. On the other hand, the number of CDEs in Turkish state universities has rapidly increased, especially since 2010. Supporting these CDEs in terms of infrastructure (network, LMS, etc.) and personnel might enable them to work more effectively. At this point, instructional technologists can be used more intensively. They can play an important role in alleviating the lack of in-service training in DE, by means of creating a DE guide, ensuring material production support, etc. Lastly, the removal of physical barriers to access to schools results in increased cultural diversity among students. This can lead to the national educational institutions, especially the universities, eluding their regional limitations and gaining a global character. In this sense, the presence of different language options along with the mother tongue can be a springboard for global students to be embraced in DE. In addition, interventions that facilitate access to digital content ensure fair access and eliminate inequality of opportunity in education. Therefore, the CDE pages on university websites 
should also be arranged for those with disabilities to increase their functionality and accessibility. To give some ideas for future research, since universities continued DE entirely in the subsequent academic terms following the EDE process, further research to obtain snapshots of universities' DE experience based on criteria employed in the present study appears to be highly beneficial. It would provide valuable insights that may reveal to what extent the experience of the rapid transition to EDE was utilized in the DE process by higher education institutions so as to remedy the deficiencies identified in this study. Apart from this, a qualitative scholarly work retrospectively scrutinizing the EDE process from the lens of not only academic staff and institutions, but also students could be undertaken.

This study has five limitations. First, its findings are limited to YÖK's statistical data and information available on the official websites of universities. Second, private universities could not be included in the study because of manageability problems and their prevalent use of closed communication channels. Third, there may have been changes in the organizational processes of universities for DE, as the data collection process took place between 9 April and 13 May 2020 while the EDE process at universities continued dynamically. Four, video and text guides were not examined in terms of content quality. In fact, they were considered as only present/ absent within the scope of this study. Finally, this academic endeavor was situated within the Turkish higher education context and culture, therefore, the findings can only be generalized to countries like Turkey.

\section{References}

Ahmed, V., \& Opoku, A. (2021). Technology supported learning and pedagogy in times of crisis: the case of COVID-19 pandemic. Education and Information Technologies. Advance online publication. https://doi.org/10.1007/s10639-021-10706-w

Aguilar, P., \& Retamal, G. (1998). Rapid educational response in complex emergencies: A discussion document. UNESCO Institute for Education. https://files.eric.ed.gov/fulltext/ED431675.pdf Accessed 30 Aug 2020

Aksal, F. A., Gazi, Z. A., Sarı, A., Berigel, M., \& Emiroğlu, B. G. (2016). The problems and support services in Web-Based distance education: Expectations in support services. In M. P. Margarida \& S. Dora (Eds.), Handbook of research on engaging digital natives in higher education settings (pp. 362-373). IGI Global Press.

Alsabawy, A. Y., Cater-Steel, A., \& Soar, J. (2016). Determinants of perceived usefulness of e-learning systems. Computers in Human Behavior, 64, 843-858. https://doi.org/10.1016/j.chb.2016.07.065

Alsadoon, E., \& Turkestani, M. (2020). Virtual classrooms for hearing-impaired students during the Coronavirus COVID-19 Pandemic. Revista Românească pentru Educaţie Multidimensională, 12(1), 1-8. https://doi.org/10.18662/rrem/12.1sup2/240

Altınay, F., Altınay, M., Dagli, G., \& Altınay, Z. (2019). A study of knowledge management systems processes and technology in open and distance education institutions in higher education. The International Journal of Information and Learning Technology, 36(4), 314-321. https://doi.org/10.1108/ IJILT-02-2019-0020

Arif, M., Ameen, K., \& Rafiq, M. (2017). Assessing distance education students satisfaction with web-based services. Online Information Review, 41(2), 202-218. https://doi.org/10.1108/ OIR-07-2016-0172

Ateş, Ö. T. (2014). Data evaluation of distance education at college level. Journal of Bayburt Education Faculty, 9(1), 22-40.

Banati, H., Bedi, P., \& Grover, P. S. (2006). Evaluating web usability from the user's perspective. Journal of Computer Science, 2(4), 314-317. https://doi.org/10.3844/jcssp.2006.314.317 
Berelson, B. (1952). Content analysis in communication research. Free Press.

Betancourt, T. S., Simmons, S., Borisova, I., Brewer, S. E., Iweala, U., \& Soudière, M. D. (2008). High hopes, grim reality: Reintegration and the education of former child soldiers in Sierra Leone. Comparative Education Review, 52(4), 565-587. https://doi.org/10.1086/591298

Bilgiç, H. G., Doğan, D., \& Seferoğlu, S. S. (2011). Current situation of online learning in Turkish higher education institutions: Needs, problems, and possible solutions. Journal of Higher Education (turkey), 1(2), 80-87. https://doi.org/10.2399/yod.11.080

Bilgiç, H. G., \& Tüzün, H. (2020). Issues and challenges with Web-based distance education programs in Turkish higher education institutes. Turkish Online Journal of Distance Education, 21(1), 143-164. https://doi.org/10.17718/tojde.690385

Bringula, R. P. (2013). Influence of faculty and web portal design-related factors on web portal usability: A hierarchical regression analysis. Computers \& Education, 68, 187-198. https://doi.org/10.1016/j. compedu.2013.05.008

Boulton, J. (2002). Web-based distance education: Pedagogy, epistemology, and instructional design. https://citeseerx.ist.psu.edu/viewdoc/download?doi=10.1.1.115.782\&rep=rep1\&type=pdf. Accessed 5 Sep 2021.

Callahan, E., \& Herring, S. C. (2012). Language choice on university websites: Longitudinal trends. International Journal of Communication, 6, 322-355.

Chen, C. M., \& Wu, C. H. (2015). Effects of different video lecture types on sustained attention, emotion, cognitive load, and learning performance. Computers \& Education, 80, 108-121. https://doi.org/10. 1016/j.compedu.2014.08.015

Chiu, C. M., Hsu, M. H., Sun, S. Y., Lin, T. C., \& Sun, P. C. (2005). Usability, quality, value and e-learning continuance decisions. Computers \& Education, 45(4), 399-416. https://doi.org/10.1016/j. compedu.2004.06.001

Coman, C., Țîru, L. G., Meseșan-Schmitz, L., Stanciu, C., \& Bularca, M. C. (2020). Online teaching and learning in higher education during the Coronavirus pandemic: Students' perspective. Sustainability, 12(24), 10367. https://doi.org/10.3390/su122410367

Czerkawski, B. C., \& Lyman, E. W. (2016). An instructional design framework for fostering student engagement in online learning environments. TechTrends, 60(6), 532-539. https://doi.org/10.1007/ s11528-016-0110-Z

Çınar, M., Ekici, M., \& Demir, Ö. (2021). Medication or Band-aid? Revisiting university students' readiness for online education. Turkish Online Journal of Distance Education, 22(2), 176-191, Article 11. https://doi.org/10.17718/tojde.906848

Demir, Ö. (2015). Öğrencilerin ve öğretim elemanlarının e-öğrenmeye hazır bulunuşluk düzeylerinin incelenmesi: Hacettepe Üniversitesi ĕ̆itim fakültesi örne ği [The investigation of e-learning readiness of students and faculty members: Hacettepe University faculty of education example] (Publication No: 381420) [Unpublished doctoral dissertation, Hacettepe University]

Demir, Ö., \& Yurdugül, H. (2015a). The exploration of models regarding e-learning readiness: Reference model suggestions. International Journal of Progressive Education, 11(1), 173-194.

Demir, Ö., \& Yurdugül, H. (2015b). Investigation of effect of e-learning readiness levels of academic staff on those of universities [Paper Presentation]. International Business \& Education Conferences, New York City, New York, USA.

Dhawan, S. (2020). Online Learning: A Panacea in the Time of COVID-19 Crisis. Journal of Educational Technology Systems, 49(1), 5-22. https://doi.org/10.1177/0047239520934018

Erdem-Aydin, İ. (2021). Investigation of higher education instructors' perspectives towards emergency remote teaching. Educational Media International, 58(1), 78-98. https://doi.org/10.1080/09523987. 2021.1908501

Fischer, C., Xu, D., Rodriguez, F., Denaro, K., \& Warschauer, M. (2020). Effects of course modality in summer session: Enrollment patterns and student performance in face-to-face and online classes. The Internet and Higher Education, 45.https://doi.org/10.1016/j.iheduc.2019.100710

Fox, R. (2007). ICT use during SARS: Teachers' experiences. Journal of Technology and Teacher Education, 15(2), 191-205.

Fraenkel, J. R., \& Wallen, N. E. (2006). How to design and evaluate research in education (6th ed.). McGraw-Hill Press.

Fung, A. C., \& Ledesma, J. (2005). Extending the classroom: The virtual integrated teaching and learning environment (VITLE). In A. Tatnall, J. Osorio, \& A. Visscher (Eds.), Information technology and educational management in the knowledge society (ITEM 2004) [pp. 47-56]. Springer Press. https:// doi.org/10.1007/0-387-24045-4_5 
García-Peñalvo, F. J., Conde, M. Á., Alier, M., \& Casany, M. J. (2011). Opening learning management systems to personal learning environments. Journal of Universal Computer Science, 17(9), 12221240. https://doi.org/10.3217/jucs-017-09-1222

Garg, A., Shukla, B., \& Kendall, G. (2015). Barriers to implementation of IT in educational institutions. The International Journal of Information and Learning Technology, 32(2), 94-108. https://doi.org/ 10.1108/IJILT-11-2014-0026

Günay, D., \& Günay, A. (2011). Quantitative developments in Turkish higher education since 1933. Journal of Higher Education and Science, 1(1), 1-22. https://doi.org/10.5961/jhes.2011.001

Hodges, C., Moore, S., Lockee, B., Trust, T., \& Bond, A. (2020). The difference between emergency remote teaching and online learning. https://er.educause.edu/articles/2020/3/the-difference-betwe en-emergency-remote-teaching-and-online-learning Accessed 15 Sept 2020

Jung, I., Wong, T. M., Li, C., Baigaltugs, S., \& Belawati, T. (2011). Quality assurance in Asian distance education: Diverse approaches and common culture. The International Review of Research in Open and Distributed Learning, 12(6), 63-83. https://doi.org/10.19173/irrodl.v12i6.991

Kagawa, F. (2005). Emergency education: A critical review of the field. Comparative Education, 41(4), 487-503. https://doi.org/10.1080/03050060500317620

Katsanos, C., Tselios, N., \& Avouris, N. (2010). A survey of tools supporting design and evaluation of websites based on models of human information interaction. International Journal on Artificial Intelligence Tools, 19(6), 755-781. https://doi.org/10.1142/S0218213010000418

Kokoç, M., IIgaz, H., \& Altun, A. (2020). Effects of sustained attention and video lecture types on learning performances. Educational Technology Research and Development, 68(6), 3015-3039. https:// doi.org/10.1007/s11423-020-09829-7

Krippendorff, K. (2018). Content analysis: An introduction to its methodology (4th ed.). Sage Press.

Lane, A. (2012). A review of the role of national policy and institutional mission in European distance teaching universities with respect to widening participation in higher education study through open educational resources. Distance Education, 33(2), 135-150. https://doi.org/10.1080/01587919. 2012.692067

Lee, K. (2020). Who opens online distance education, to whom, and for what? Distance Education, 41(2), 186-200. https://doi.org/10.1080/01587919.2020.1757404

Li, F. (2018). The expansion of higher education and the returns of distance education in China. The International Review of Research in Open and Distributed Learning, 19(4), 242-256. https://doi. org/10.19173/irrodl.v19i4.2881

Margaryan, A., Bianco, M., \& Littlejohn, A. (2015). Instructional quality of Massive Open Online Courses (MOOCs). Computers \& Education, 80, 77-83. https://doi.org/10.1016/j.compedu.2014. 08.005

McGee, P., Windes, D., \& Torres, M. (2017). Experienced online instructors: Beliefs and preferred supports regarding online teaching. Journal of Computing in Higher Education, 29(2), 331-352. https://doi.org/10.1007/s12528-017-9140-6

Ming, Y. (2020). Digital services in academic libraries: Present and future. Public Services Quarterly, 16(1), 59-64. https://doi.org/10.1080/15228959.2019.1706692

Moore, M. G. (1993). Theory of transactional distance. In D. Keegan (Ed.), Theoretical principles of distance Education (pp. 22-38). Routledge Press.

Moore, M. G., \& Kearsley, G. (1996). Distance education: A systems view. Wadsworth Press.

Murphy, A. (2013). Open educational practices in higher education: Institutional adoption and challenges. Distance Education, 34(2), 201-217. https://doi.org/10.1080/01587919.2013.793641

Mutlu-Bayraktar, D. (2016). Investigation of website usability of the website facility of open university via an eye tracking method [Paper Presentation]. 2016 Amsterdam International Academic Conference, Amsterdam, Netherlands. https://docplayer.net/64711005-Gai-international-academic-confe rences-proceedings.html Accessed 14 Sept 2020

Nicolai, S., \& Triplehorn, C. (2003). The role of education in protecting children in conflict. Overseas Development Institute. https://www.odi.org/sites/odi.org.uk/files/odi-assets/publications-opinionfiles/520.pdf Accessed 16 Sept 2020

Ortagus, J. C. (2017). From the periphery to prominence: An examination of the changing profile of online students in American higher education. The Internet and Higher Education, 32, 47-57. https://doi.org/10.1016/j.iheduc.2016.09.002

Palvia, S., Aeron, P., Gupta, P., Mahapatra, D., Parida, R., Rosner, R., \& Sindhi, S. (2018). Online education: Worldwide status, challenges, trends, and implications. Journal of Global Information Technology Management, 21(4), 233-241. https://doi.org/10.1080/1097198X.2018.1542262 
Pereira, L., \& Guerreiro, J. (2021). Evaluation on Moodle LMS data usage during the first wave of Covid-19's pandemic. In M. Antona \& C. Stephanidis (Eds.), Universal access in human-computer interaction. Access to Media, Learning and Assistive Environments (pp. 154-166). Springer International Press.

Pinto, M., \& Leite, C. (2020). Digital technologies in support of students learning in Higher Education: Literature review. Digital Education Review, 37, 343-360. https://doi.org/10.1344/der.2020.37. 343-360

Piskurich, G. M. (2009). Rapid training development: Developing training courses fast and right. Pfeiffer Press.

Power, M. (2009). A designer's log: Case studies in instructional design. Athabasca University Press.

Rapanta, C., Botturi, L., Goodyear, P., Guàrdia, L., \& Koole, M. (2020). Online university teaching during and after the Covid-19 crisis: Refocusing teacher presence and learning activity. Postdigital Science and Education, 2(3), 923-945. https://doi.org/10.1007/s42438-020-00155-y

Rejón-Guardia, F., Polo-Peña, A. I., \& Maraver-Tarifa, G. (2020). The acceptance of a personal learning environment based on Google apps: The role of subjective norms and social image. Journal of Computing in Higher Education, 32(2), 203-233. https://doi.org/10.1007/s12528-019-09206-1

Retamal, G., \& Aedo-Richmond, R. (Eds.). (1998). Education as a humanitarian response. Cassell Press.

Rhode, J., Richter, S., Gowen, P., Miller, T., \& Wills, C. (2017). Understanding faculty use of the learning management system. Online Learning, 21(3), 68-86. https://doi.org/10.24059/olj.v21i3.1217

Richter, T., \& McPherson, M. (2012). Open educational resources: Education for the world? Distance Education, 33(2), 201-219. https://doi.org/10.1080/01587919.2012.692068

Riffe, D., Lacy, S., Fico, F., \& Watson, B. (2019). Analyzing media messages: Using quantitative content analysis in research (4th ed.). Routledge Press.

Sakala, L. C., \& Chigona, W. (2020). How lecturers neutralize resistance to the implementation of learning management systems in higher education. Journal of Computing in Higher Education, 32(2), 365-388. https://doi.org/10.1007/s12528-019-09238-7

Sandars, J., Correia, R., Dankbaar, M., de Jong, P., Goh, P. S., Hege, I., et al. (2020). Twelve tips for rapidly migrating to online learning during the COVID-19 pandemic. MedEdPublish, 9. https://doi.org/ 10.15694/mep.2020.000082.1

Shearer, R. L., Aldemir, T., Hitchcock, J., Resig, J., Driver, J., \& Kohler, M. (2020). What students want: A Vision of a future online learning experience grounded in distance education theory. American Journal of Distance Education, 34(1), 36-52. https://doi.org/10.1080/08923647.2019.1706019

Sinclair, M. (2002). Planning education in and after emergencies. UNESCO, International Institute for Educational Planning. https://unesdoc.unesco.org/ark:/48223/pf0000129356 Accessed 25 Sept 2020

Singh, M., Adebayo, S. O., Saini, M., \& Singh, J. (2021). Indian government E-learning initiatives in response to COVID-19 crisis: A case study on online learning in Indian higher education system. Education and Information Technologies, 1-39. Advance online publication. https://doi.org/10. 1007/s10639-021-10585-1

Trust, T., \& Whalen, J. (2020). Should teachers be trained in emergency remote teaching? Lessons learned from the COVID-19 pandemic. Journal of Technology and Teacher Education, 28(2), 189199. https://www.learntechlib.org/primary/p/215995/

Tüzün, H. (2001). Guidelines for converting existing courses into web-based format [Paper Presentation]. 24th National Convention of the Association for Educational Communications and Technology. Atlanta, GA, USA. http://files.eric.ed.gov/fulltext/ED470167.pdf. Accessed 5 Dec 2020.

Tüzün, H., \& Çınar, M. (2016). Guidelines for transferring residential courses into Web. International Review of Research in Open and Distributed Learning, 17(4), 145-165. https://doi.org/10.19173/ irrodl.v17i4.2323

van der Meij, H., \& van der Meij, J. (2014). A comparison of paper-based and video tutorials for software learning. Computers \& Education, 78, 150-159. https://doi.org/10.1016/j.compedu.2014.06.003

van Rooij, S. W., \& Zirkle, K. (2016). Balancing pedagogy, student readiness and accessibility: A case study in collaborative online course development. Internet and Higher Education, 28, 1-7. https:// doi.org/10.1016/j.iheduc.2015.08.001

West, R. E., Thomas, R. A., Bodily, R., Wright, C., \& Borup, J. (2017). An analysis of instructional design and technology departments. Educational Technology Research and Development, 65(4), 869-888. https://doi.org/10.1007/s11423-016-9490-1

YÖK. (2020a). YÖK bilgi yönetim sistemi [YÖK information management system]. https://istatistik.yok. gov.tr. Accessed 6 May 2020 
YÖK. (2020b). Yükseköğretim kurumlarında uzaktan öğretime ilişkin usul ve esaslar [Procedures and principles regarding distance education in higher education institutions]. https://www.yok.gov.tr/ Documents/Kurumsal/egitim_ogretim_dairesi/Uzaktan_ogretim/yuksekogretim_kurumlarinda_ uzaktan_ogretime_iliskin_usul_ve_esaslar.pdf Accessed 6 May 2020

YÖK. (2020c). YÖK, engelli öğrencilerin uzaktan e ğitimde yaşadı̆̆ slkıntılara yönelik harekete geçti [YÖK took action against the difficulties experienced by disabled students in distance education]. https://covid19.yok.gov.tr/Documents/alinan-kararlar/18-engelli-ogrencilerin-uzaktan-egitimi.pdf Accessed 7 May 2020

Yurdugül, H., \& Demir, Ö. (2017). Öğretmen yetiştiren lisans programlarındaki öğretmen adaylarının e-öğrenmeye hazır bulunuşluklarının incelenmesi: Hacettepe üniversitesi örneği [An investigation of pre-service teachers' readiness for e-learning at undergraduate level teacher training programs: The case of Hacettepe university]. Hacettepe University Journal of Education, 32(4), 896-915. https://doi.org/10.16986/HUJE.2016022763

Zawacki-Richter, O., Bozkurt, A., Alturki, U., \& Aldraiweesh, A. (2018). What research says about MOOCs - An explorative content analysis. International Review of Research in Open and Distributed Learning, 19(1), 242-259. https://doi.org/10.19173/irrodl.v19i1.3356

Zawacki-Richter, O., \& Naidu, S. (2016). Mapping research trends from 35 years of publications in Distance Education. Distance Education, 37(3), 245-269. https://doi.org/10.1080/01587919.2016. 1185079

Publisher's note Springer Nature remains neutral with regard to jurisdictional claims in published maps and institutional affiliations. 